\title{
KERAGAAN PERTUMBUHAN VEGETATIF DAN REPRODUKTIF HIBRIDA JAGUNG PERSILANGAN GALUR INBRIDA MUTAN (M4) PADA LATOSOL DARMAGA
}

\author{
Rustikawati $^{1}$, Catur Herison ${ }^{1}$ Surjono H. Sutjahjo ${ }^{2}$ \\ ${ }^{1}$ Jurusan Budidaya Pertanian, Fakultas Pertanian, Universitas Bengkulu \\ Jl WR. Supratman, Kandang Limun, Bengkulu 38371A \\ ${ }^{2}$ Departemen Agrohort, Fakultas Pertanian, Institut Pertanian Bogor \\ Jl Raya Darmaga, Bogor 16680 \\ rustikawati@unib.ac.id
}

\begin{abstract}
[VEGETATIVE AND REPRODUCTIVE PERFORMANCES OF MAIZE HYBRIDS GENERATED FROM INBRED MUTANTS (M4) ON DARMAGA LATOSOL]. The development of hybrids from local germplasms are extensively done as alternative to the expensive imported hybrid seeds. The farthest genetic distance of parental lines is required to develop the best hybrids. The objective of this study was to compare the vegetative and reproductive performances of hybrids generated from crosses of M4 inbred lines, generated from the selected gamma irradiated mutants. Twenty eight hybrids derived from diallel crosses of M4 inbred lines and a check hybrid variety (NK33) were evaluated on Darmaga latosol. The results showed that all hybrids had lower performances on vegetative and reproductive characters compared to NK33. However, based on the selection index involving all characters, hybrids of G3 x G8, G6 x G8, and G8 x G6 with the index values of $9.45,7.85$, and 6.72 , respectively, performed better than or similar to NK33.
\end{abstract}

Keyword: maize hybrid, mutation, selection index

\begin{abstract}
ABSTRAK
Perakitan hibrida dari plasma nutfah lokal akhir-akhir ini banyak dilakukan sebagai alternatif terhadap benih impor yang mahal. Pada tanaman jagung, pembentukan galur dengan jarak genetik yang jauh sangat diperlukan agar diperoleh hybrid vigor tinggi pada persilangannya. Penelitian ini bertujuan untuk membandingkan keragaan hibrida dari persilangan galur-galur inbred M4 hasil seleksi mutant iradiasi sinar gamma. Dua puluh delapan hibrida persilangan dialel dari galur-galur M4 dan satu hibrida pembanding (NK33) dievaluasi pada Latosol Darmaga. Hasil penelitian menunjukkan bahwa pertumbuhan vegetatif dan generatif semua hibrida yang diuji pada beberapa karakter penting belum bisa melebihi hibrida pembanding NK33. Namun berdasarkan indeks seleksi yang disusun dari semua karakter, maka hibrida G3 x G8, G6 x G8, G8 x G6 dengan nilai indeks berturut-turut 9.45, 7.85, dan 6.72, memiliki penampilan lebih baik atau sama dengan hibrida komersial NK33.
\end{abstract}

Kata kunci: jagung hibrida, mutasi, indeks seleksi 


\section{PENDAHULUAN}

Perkembangan produksi jagung di Indonesia selama lima tahun terakhir mengalami peningkatan yang cukup berarti. Produksi jagung nasional tahun 2008 sebesar 16.32 juta ton pipilan kering. Pada tahun 2009, produksi meningkat menjadi 17.66 juta ton (BPS, 2010). Peningkatan produksi jagung terutama disebabkan oleh peningkatan produktivitas akibat perubahan varietas yang ditanam petani dari varietas lokal ke varietas komposit atau hibrida. Sayangnya, hampir semua hibrida yang ditanam petani berasal dari benih impor yang harganya mahal dan seringkal terbatas ketersediaannya.

Berbagai penelitian telah banyak dilakukan oleh pemulia tanaman dalam rangka perakitan kultivar hibrida jagung. Taufik et al. (2009) berhasil mendapatkan hibrida double cross yang potensial untuk lahan marginal dengan produksi 5.07 ton $\mathrm{ha}^{-1}$. Produksi tersebut lebih tinggi dari hibrida komersial Prima-1 dan DK-3 pada lahan ultisol yang masingmasing 3.7 ton ha ${ }^{-1}$ dan 4.41 ton ha ${ }^{-1}$. Potensi tersebut masih dapat ditingkatkan jika hibrida yang digunakan berasal dari persilangan galur inbrida dengan jarak genetik yang jauh dengan efek heterosis tinggi.

Mutasi induksi dengan sinar gamma merupakan alternatif untuk meningkatkan keragaman genetik plasma nutfah. Mutasi dapat disebut sebagai perubahan materi genetik pada tingkat genom, kromosom, dan DNA atau gen sehingga menyebabkan terjadinya keragaman genetik (Soeranto, 2003). Para peneliti yang bekerjasama dengan P3TIR-BATAN secara aktif melakukan pembentukan galur-galur mutan beberapa tanaman pangan melalui radiasi sinar gamma serta seleksi galur mutan untuk berbagai tujuan (P3TIR BATAN, 2000). Tanaman pangan yang sedang diteliti meliputi sorghum, padi, kacang merah, kedelai, dan kacang tanah. Dari hasil penelitian ini akan dirilis 6 varietas padi yang tahan wereng coklat (biotype 2 dan 3 ) serta tahan terhadap bercak daun, 1 varietas kacang merah tahan terhadap kekeringan dan bercak Cercospora, serta 3 varietas kedelai tahan terhadap lahan masam dan keracunan aluminium.

Induksi mutasi pada jagung untuk meningkatkan keragaman genetik plasma nutfah dalam rangka pembentukan galur mutan jagung telah dilakukan oleh Rustikawati et al. (2008). Generasi M1 (kecambah yang tumbuh dari benih yang diradiasi) telah diteliti dan diseleksi pada tahun 1997. Tanaman M1 bersifat heterozigot akibat gen-gen mutan yang baru, dan akan bersegregasi menjadi fenotipe mutan dan non-mutan pada generasi M2. Mutan resesif yang baru terinduksi akan terekspresi dan dapat diamati pada generasi M2, setelah tanaman M1 menyerbuk sendiri (Ahnstroem, 1977). Identifikasi dan isolasi mutan pada tanaman yang menyerbuk silang membutuhkan kontrol polinasi pada saat pembentukan generasi M2. Generasi lanjutan yang berasal silang dalam M2 diberi istilah M3, M4 dan seterusnya (Micke and Donini, 1993).

Penelitian ini merupakan rangkaian kegiatan perakitan hibrida jagung dalam rangka ikut mendukung progran swa sembada jagung yang dicanangkan pemerintah. Secara khusus penelitian bertujuan untuk membandingkan keragaan 28 persilangan galur M4 mutan hasil irradiasi sinar gamma.

\section{METODE PENELITIAN}

Penelitian dilakukan pada Agustus sampai November 2009. Hibrida yang dievaluasi meliputi 28 persilangan dialel dari 6 galur M4 dan satu hibrida pembanding NK33. Keenam galur yang disilangkan adalah: G1-12-18a-1, G3-15-17-4, G66-19-19', G7-15-9-3, G8-4-8-6, G9-20-44-2. Evaluasi dilakukan pada latosol Darmaga, Bogor berdasarkan rancangan acak lengkap dengan 3 ulangan. Penanaman dilakukan pada petak percobaan berukuran $225 \mathrm{~cm} \times 150 \mathrm{~cm}$ dengan jarak tanam dalam baris $25 \mathrm{~cm}$ dan antar baris $75 \mathrm{~cm}$. Pupuk dasar yang diberikan adalah urea $100 \mathrm{~kg} \mathrm{ha}^{-1}, \mathrm{KCl} 100 \mathrm{~kg} \mathrm{ha}^{-1}$ dan TSP $100 \mathrm{~kg} \mathrm{ha}^{-1}$. Pupuk urea ditambahkan lagi pada umur 1 bulan setelah tanam sebanyak $100 \mathrm{~kg}$ $\mathrm{ha}^{-1}$ bersamaan dengan pembumbunan tanaman.

Pengamatan dilakukan terhadap tiga tanaman sampel pada karakter vegetatif yang meliputi tinggi tanaman, jumlah daun, panjang daun, lebar daun dan diameter batang dan karakter reproduktif yang meliputi umur bunga betina muncul, umur bunga jantan muncul, jumlah bunga betina dan jumlah tongkol tiap tanaman. Analisis varian dilakukan terhadap data yang dihimpun dengan uji $\mathrm{F}$ pada $\alpha=$ $5 \%$ dan perbandingan rata-rata dilakukan dengan DMRT pada $\alpha=5 \%$.

Indeks seleksi disusun dari beberapa karakter untuk menentukan persilangan terbaik. Sumbangan karakter yang dilibatkan dalam penyusunan indek seleksi ditentukan berdasarkan nilai ekonomi sesuai dengan tujuan pemuliaan (Banziger et al., 2000), sebagai berikut.

$$
\mathrm{I}=\mathrm{W}_{1} \mathrm{X}_{1}+\mathrm{W}_{2} \mathrm{X}_{2}+\mathrm{W}_{3} \mathrm{X}_{3}+\ldots+\mathrm{W}_{\mathrm{p}} \mathrm{X}_{\mathrm{p}}
$$

Keterangan: $\mathrm{I}=$ indeks seleksi, $\mathrm{W}=$ bobot ekonomis masing-masing karakter, dan $\mathrm{X}=$ rata-rata yang 
telah distandarisasi, $1,2,3, \ldots, p=$ karakter yang dilibatkan dalam indeks. Karakter yang terstandarisasi didefinisikan mempunyai rata-rata 0 dan ragam 1 .

\section{HASIL DAN PEMBAHASAN}

Tinggi tanaman merupakan karakter penting dan biasanya digunakan sebagai indikator pertumbuhan tanaman. Dari 28 persilangan yang diuji, G6 x G9 merupakan hibrida yang tertinggi dan berbeda nyata dengan NK33. Sayangnya, tanaman tertinggi tidak disertai dengan diameter batang terbesar. Pada tanaman jagung, semakin tinggi tanaman akan berpeluang semakin mudah rebah jika tidak disertai dengan bertambahnya diameter batang. Diameter batang terbesar dimiliki oleh persilangan G3 x G6 yang tidak berbeda nyata dengan NK33. Persilangan lain yang memiliki diameter batang sama dengan NK33 adalah G1 x G6, G3 x G8, G3 x G9, G7 x G3, G8 x G1, G8 xG3 dan G9 x G3 (Tabel 1).

Karakter yang langsug berhubungan dengan aktivitas fotosintesis tanaman adalah jumlah daun, panjang daun dan lebar daun. Semakin banyak jumlah daun dan semakin besar luas daun dapat dipastikan semakin besar jumlah asimilat yang dihasilkan dari proses fotosintesis. Dari seluruh hibrida yang diuji, hibrida yang memiliki sekaligus ketiga karakter dengan nilai tertingi atau tinggi adalah NK33. Hibrida komersial tersebut memiliki panjang daun tertinggi serta jumlah daun dan lebar daun kedua tertinggi. Jumlah daun tertinggi dimiliki oleh persilangan G8 x G1, sedangkan lebar daun tertinggi pada persilangan G3 x G9. Berbeda dengan NK33, kedua persilangan tersebut memiliki nilai

Tabel 1. Rata-rata tinggi tanaman, diameter batang, jumlah daun, panjang daun dan lebar daun pada umur 8 mst

\begin{tabular}{|c|c|c|c|c|c|c|c|c|c|c|}
\hline \multirow{2}{*}{$\begin{array}{l}\text { Persilangan } \\
\text { G1 x G6 }\end{array}$} & \multicolumn{2}{|c|}{$\begin{array}{l}\text { Tinggi Tanaman } \\
(\mathrm{cm})\end{array}$} & \multicolumn{2}{|c|}{$\begin{array}{c}\text { Diameter } \\
\text { Batang } \\
(\mathrm{mm})\end{array}$} & \multicolumn{2}{|c|}{ Jumlah Daun } & \multicolumn{2}{|c|}{$\begin{array}{l}\text { Panjang Daun } \\
(\mathrm{cm})\end{array}$} & \multicolumn{2}{|c|}{$\begin{array}{l}\text { Lebar Daun } \\
\qquad(\mathrm{cm})\end{array}$} \\
\hline & 218.80 & $\mathrm{gh}$ & 23.11 & abcde & 12.43 & bcde & 90.33 & cdefgh & 9.19 & defg \\
\hline G1 x G7 & 240.43 & cdef & 20.61 & defg & 12.43 & bcde & 92.86 & bcdef & 9.46 & de \\
\hline G1 x G8 & 246.00 & cde & 20.91 & defg & 12.63 & bcd & 90.18 & cdefgh & 8.25 & $\mathrm{~h}$ \\
\hline G1 x G9 & 230.35 & defgh & 20.34 & efg & 11.00 & fgh & 91.53 & bcdefg & 10.33 & $\mathrm{bc}$ \\
\hline G3 x G6 & 233.28 & defg & 26.02 & $\mathrm{a}$ & 12.56 & bcde & 96.56 & $a b c$ & 8.74 & efgh \\
\hline G3 x G7 & 222.25 & fgh & 22.09 & bcdef & 11.64 & cdefg & 86.06 & fghi & 9.05 & defgh \\
\hline G3 x G8 & 237.57 & def & 24.38 & $a b c$ & 11.33 & efgh & 94.70 & abcd & 8.57 & fgh \\
\hline G3 x G9 & 200.15 & i & 23.73 & abcd & 11.50 & defg & 85.38 & ghi & 20.07 & $\mathrm{a}$ \\
\hline G6 x G1 & 222.39 & fgh & 21.92 & bcdef & 12.50 & bcde & 90.58 & bcdefgh & 8.94 & defgh \\
\hline G6 x G3 & 238.80 & cdef & 23.35 & abcde & 11.75 & cdefg & 84.15 & hi & 9.19 & defg \\
\hline G6 x G7 & 233.53 & defg & 21.40 & cdefg & 12.11 & cdefg & 87.84 & defghi & 8.62 & efgh \\
\hline G6 x G8 & 238.98 & cdef & 20.31 & efg & 12.20 & cdef & 96.17 & $a b c$ & 8.99 & defgh \\
\hline G6 x G9 & 288.43 & $\mathrm{a}$ & 21.62 & cdef & 11.50 & defg & 91.17 & bcdefgh & 8.70 & efgh \\
\hline G7 x G1 & 222.03 & fgh & 20.44 & defg & 11.33 & efgh & 87.86 & defghi & 8.69 & efgh \\
\hline G7 x G3 & 233.06 & defg & 23.46 & abcde & 11.14 & fgh & 91.11 & bcdefgh & 8.71 & efgh \\
\hline G7 x G6 & 247.50 & cd & 22.24 & bcde & 11.88 & cdefg & 90.46 & bcdefgh & 8.48 & fgh \\
\hline G7 x G8 & 236.50 & defg & 16.24 & $\mathrm{~h}$ & 11.00 & fgh & 81.94 & $\mathrm{i}$ & 8.96 & defgh \\
\hline G7 x G9 & 243.12 & cde & 17.04 & $\mathrm{~h}$ & 10.89 & $\mathrm{gh}$ & 90.04 & cdefgh & 9.24 & def \\
\hline G8 x G1 & 147.40 & $\mathrm{j}$ & 25.12 & $a b$ & 14.50 & $\mathrm{a}$ & 70.19 & $\mathrm{j}$ & 8.24 & $\mathrm{~h}$ \\
\hline G8 x G3 & 239.62 & cdef & 23.65 & abcde & 11.50 & defg & 96.73 & $a b c$ & 8.85 & efgh \\
\hline G8 x G6 & 265.55 & $\mathrm{~b}$ & 21.23 & cdefg & 12.75 & $\mathrm{bc}$ & 97.46 & $a b$ & 9.74 & $\mathrm{~cd}$ \\
\hline G8 x G7 & 229.26 & defgh & 21.07 & cdefg & 11.89 & cdefg & 86.84 & efghi & 8.31 & gh \\
\hline G8 x G9 & 231.66 & defgh & 16.16 & $\mathrm{~h}$ & 11.78 & cdefg & 87.67 & defghi & 9.27 & def \\
\hline G9 x G1 & 228.38 & efgh & 21.48 & cdefg & 12.50 & bcde & 93.33 & bcde & 10.22 & $\mathrm{c}$ \\
\hline G9 x G3 & 238.19 & cdef & 23.64 & abcde & 12.00 & cdefg & 86.91 & efghi & 8.33 & gh \\
\hline G9 x G6 & 256.10 & $\mathrm{bc}$ & 20.70 & defg & 11.78 & cdefg & 90.68 & bcdefgh & 9.31 & def \\
\hline G9 x G7 & 213.66 & hi & 18.23 & gh & 10.25 & $\mathrm{~h}$ & 82.15 & $\mathrm{i}$ & 8.97 & defgh \\
\hline G9 x G8 & 239.30 & cdef & 18.80 & fghi & 11.89 & cdefg & 86.84 & efghi & 8.66 & efgh \\
\hline NK33 & 237.64 & def & 23.40 & abcde & 13.38 & $\mathrm{~b}$ & 101.15 & $\mathrm{a}$ & 10.98 & $\mathrm{~b}$ \\
\hline
\end{tabular}

Rata-rata sekolom diikuti huruf sama berarti berbeda tidak nyata pada DMRT ( $\alpha=5 \%)$. 
tertinggi hanya pada satu karakter diantara tiga karakter yang berperan dalam fotosintesis. Oleh karena itu, berdasarkan pengamatan terhadap karakter vegetatif, hibrida yang diuji belum bisa menyamai hibrida pembanding NK33. Pertumbuhan vegetatif hibrida yang diuji kurang optimal diduga disebabkan karena proses pembentukan galur baru sampai generasi keempat. Untuk tanaman menyerbuk silang, karakteristik sifat-sifat kuantitatif pada galur tidak bisa muncul karena tereksposenya gen-gen resesif. Namun demikian, jika pembentukan galur telah sempurna maka pada persilangan antar galur akan terjadi hybrid vigor terutama pada karakter kuantitatif (Hallauer and Miranda, 1988).
Karakter reproduktif diamati sejak munculnya bunga betina dan bunga jantan. Bunga jantan muncul lebih cepat dibandingkan bunga betina pada semua hibrida yang diuji (Tabel 2). Hibrida NK33 memiliki nilai tertinggi pada munculnya bunga betina dan bunga jantan Tanaman yang bunganya muncul lebih cepat akan panen lebih cepat. Dengan demikian hibrida NK33 berumur paling panjang dibandingkan semua hibrida yang diuji.

Pengamatan terhadap jumlah bunga betina dan jumlah tongkol pada semua hibrida hampir tidak menunjukkan perbedaan yang nyata pada semua hibrida. Jumlah bunga betina yang muncul rata-rata antara 2 sampai 3, tetapi jumlah tongkol yang

Tabel 2. Rata-rata umur bunga betina muncul, umur bunga jantan muncul, jumlah bunga betina dan jumlah tongkol tiap tanaman

\begin{tabular}{|c|c|c|c|c|c|c|c|c|c|c|}
\hline \multirow{2}{*}{$\begin{array}{l}\text { Persilangan } \\
\text { G1 x G6 }\end{array}$} & \multicolumn{2}{|c|}{$\begin{array}{l}\text { Umur Bunga } \\
\text { Betina (hari) }\end{array}$} & \multicolumn{2}{|c|}{$\begin{array}{l}\text { Umur Bunga } \\
\text { Jantan (hari) }\end{array}$} & \multicolumn{2}{|c|}{$\begin{array}{c}\text { Jumlah Bunga } \\
\text { Betina }\end{array}$} & \multicolumn{2}{|c|}{$\begin{array}{l}\text { Jumlah } \\
\text { Tongkol }\end{array}$} & \multicolumn{2}{|c|}{$\begin{array}{c}\text { Bobot Tongkol } \\
(\mathrm{g})\end{array}$} \\
\hline & 48.71 & bcd & 46.14 & b & 2.71 & abcd & 1.71 & $\mathrm{ab}$ & 130.11 & cdefgh \\
\hline G1 x G7 & 47.14 & cdef & 44.57 & $\mathrm{~cd}$ & 2.29 & abcde & 1.14 & $\mathrm{bc}$ & 90.66 & hi \\
\hline G1 x G8 & 50.38 & $\mathrm{~b}$ & 43.25 & defg & 2.38 & abcde & 1.63 & $a b c$ & 140.88 & bcdef \\
\hline G1 x G9 & 47.50 & cdef & 44.00 & de & 2.67 & abcd & 1.83 & $\mathrm{a}$ & 105.13 & fghi \\
\hline G3 x G6 & 44.11 & gh & 40.89 & $\mathrm{kl}$ & 3.00 & $a b c$ & 1.67 & $a b c$ & 109.89 & efghi \\
\hline G3 x G7 & 45.36 & efgh & 42.18 & fghijk & 2.09 & bcdef & 1.36 & $a b c$ & 130.23 & cdefgh \\
\hline G3 x G8 & 44.00 & gh & 41.17 & $\mathrm{jkl}$ & 2.50 & abcde & 1.50 & $a b c$ & 162.07 & $\mathrm{bc}$ \\
\hline G3 x G9 & 45.38 & efgh & 42.13 & fghijk & 1.88 & def & 1.38 & $a b c$ & 120.40 & defgh \\
\hline G6 x G1 & 49.13 & $\mathrm{bc}$ & 45.88 & $\mathrm{bc}$ & 2.25 & abcdef & 1.38 & $a b c$ & 97.58 & ghi \\
\hline G6 x G3 & 43.63 & $\mathrm{~h}$ & 40.50 & 1 & 2.25 & abcdef & 1.38 & $a b c$ & 107.83 & efghi \\
\hline G6 x G7 & 45.11 & efgh & 42.44 & efghijk & 2.44 & abcde & 1.44 & $a b c$ & 124.44 & cdefgh \\
\hline G6 x G8 & 45.90 & defgh & 43.00 & efgh & 2.00 & cdef & 1.20 & $\mathrm{bc}$ & 177.09 & $\mathrm{ab}$ \\
\hline G6 x G9 & 46.33 & cdefgh & 42.83 & efghi & 2.50 & abcde & 1.67 & $a b c$ & 116.77 & defgh \\
\hline G7 x G1 & 45.56 & efgh & 42.56 & efghij & 2.22 & abcdef & 1.67 & $a b c$ & 117.36 & defgh \\
\hline G7 x G3 & 44.57 & gfh & 41.29 & ijkl & 2.43 & abcde & 1.57 & $a b c$ & 131.71 & cdefgh \\
\hline G7 x G6 & 45.63 & efgh & 41.75 & ghijkl & 2.63 & abcde & 1.63 & $a b c$ & 123.98 & cdefgh \\
\hline G7 x G8 & 45.86 & defgh & 43.14 & defgh & 1.86 & def & 1.14 & $\mathrm{bc}$ & 104.80 & fghi \\
\hline G7 x G9 & 46.44 & cdefgh & 43.67 & def & 1.67 & def & 1.22 & $\mathrm{bc}$ & 106.13 & efghi \\
\hline G8 x G1 & 47.20 & cdef & 43.90 & $\mathrm{de}$ & 2.20 & abcdef & 1.40 & $a b c$ & 73.56 & i \\
\hline G8 x G3 & 46.00 & defgh & 42.60 & efghij & 1.90 & def & 1.30 & $a b c$ & 147.05 & bcde \\
\hline G8 x G6 & 46.38 & cdefgh & 42.63 & efghij & 2.13 & abcdef & 1.13 & $\mathrm{c}$ & 151.94 & bcd \\
\hline G8 x G7 & 46.22 & defgh & 43.00 & efgh & 1.67 & def & 1.33 & $a b c$ & 124.78 & cdefgh \\
\hline G8 x G9 & 46.78 & cdefg & 43.44 & def & 1.22 & $f$ & 1.22 & $\mathrm{bc}$ & 112.99 & defghi \\
\hline G9 x G1 & 45.17 & efgh & 41.83 & ghijkl & 3.17 & $\mathrm{a}$ & 1.83 & $\mathrm{a}$ & 105.18 & fghi \\
\hline G9 $x$ G3 & 45.00 & efgh & 41.57 & hijkl & 2.29 & abcde & 1.43 & $a b c$ & 124.87 & cdefgh \\
\hline G9 x G6 & 45.67 & efgh & 41.67 & ghijkl & 3.11 & $\mathrm{ab}$ & 1.22 & $\mathrm{bc}$ & 133.60 & cdefg \\
\hline G9 x G7 & 46.75 & cdefg & 43.67 & def & 1.58 & ef & 1.17 & $\mathrm{bc}$ & 102.02 & fghi \\
\hline G9 $x$ G8 & 47.67 & cde & 45.78 & $\mathrm{bc}$ & 2.22 & abcdef & 1.22 & $\mathrm{bc}$ & 131.13 & cdefgh \\
\hline NK33 & 59.88 & $\mathrm{a}$ & 56.13 & $\mathrm{a}$ & 2.00 & cdef & 1.13 & $\mathrm{c}$ & 204.79 & $\mathrm{a}$ \\
\hline
\end{tabular}

Rata-rata sekolom diikuti huruf sama berarti berbeda tidak nyata pada DMRT ( $\alpha=5 \%)$. 
produktif antara 1 sampai 2.Tongkol tanpa klobot ditimbang setelah dilakukan pengeringan di bawah sinar matahari selama 7 hari. Bobot tongkol hibrida yang diuji sangat bervariasi dengan nilai terendah 73.56 g (G8 x G1) hingga tertinggi 204.79 (NK33). Jika dikaitkan dengan pengamatan vegetatif, karakter jumlah daun, panjang daun dan lebar daun berperan dalam menentukan bobot tongkol.

Dalam penelitian ini persilangan dilakukan pada generasi M4 setelah irradiasi sinar gamma. Seleksi dan pengujian ditujukan untuk melihat potensi hibrida dibandingkan dengan hibrida komersial. Metode seleksi indeks dengan melibatkan semua karakter yang diamati digunakan untuk memilih hibrida harapan. Nilai pembobotan pada setiap karakter jagung bervariasi antar pemulia tanaman. Pada penelitian ini dasar pembobotan mengikuti Banziger et al. (2000). Bobot tongkol dianggap karakter yang paling berperan terhadap produksi sehingga diberi bobot empat, sedangkan karakter lainnya masing-masing diberi bobot satu. Untuk umur berbunga jantan dan umur berbunga betina diberikan notasi negatif karena menginterpretasikan kegenjahan.

Berdasarkan nilai indeks seleksi, persilangan terbaik adalah G3 x G8, G6 x G8, G8 x G6 dengan nilai indeks berturut-turut $9.45,7.85$, dan 6.72 (Tabel 3). Hibrida tersebut secara akumulatif memiliki sifat terbaik dibandingkan lainnya dan lebih baik atau sama dengan hibrida komersial NK33. Hal ini menarik karena walaupun berdasarkan pembahasan sebelumnya secara vegetatif dan reproduktif hibrida NK33 lebih unggul, namun adanya faktor pengurag dari karakter umur berbunga menjadikan ketiga hibrida yang diuji bisa memiliki nilai indeks lebih tinggi. Perbedaan umur panen antara 13 hari (G8 x G6) sampai 15 hari (G3 x G8) dengan NK33 merupakan indikasi yang baik untuk perbaikan karakter kegenjahan.

Penelitian ini memberi harapan akan diperoleh hibrida unggul jika persilangan galur mutan dilakukan pada generasi lebih lanjut. Poehlman (1987) menyatakan bahwa vigor pada hibrida jagung dapat meningkat lebih dari dua kali lipat kedua induk galur murninya. Hibrida jagung yang produksinya mempunyai tingkat heterosis tinggi diperoleh pada persilangan galur S6 hingga S10 (Zaidi et.al., 2007).

\section{KESIMPULAN}

Pertumbuhan vegetatif dan generaif semua hibrida yang diuji pada beberapa karakter penting belum bisa melebihi hibrida pembanding NK33. Namun jika diperhitungkan semua karakter dengan indeks seleksi, persilangan G3 x G8, G6 x G8, G8 x G6 dengan nilai indeks berturut-turut 9.45, 7.85, dan 6.72 secara akumulatif memiliki sifat lebih baik atau sama dengan hibrida komersial NK33. Pembentukan galur perlu dilanjutkan agar peluang memperoleh hibrida dengan potensi produksi yang tinggi dapat diperoleh.

\section{DAFTAR PUSTAKA}

Ahnstroem G. 1977. Radiobiology. In: Manual on Mutation Breeding, $2^{\text {nd }}$ edition. Tech. Report Series No.119. Joint FAO/IAEA. Vienna: Div. of Atomic Energy in Food and Agriculture. pp 21-27.

BPS. 2010. Statistik Indonesia. Biro Pusat Statistik, Jakarta.

Tabel 3. Nilai indeks seleksi hibrida jagung berdasarkan karakter yang distandarisasi

\begin{tabular}{cccccc}
\hline Persilangan & indeks & Persilangan & indeks & Persilangan & indeks \\
\hline G1 x G6 & 2.26 & G6 x G7 & 0.98 & G8 x G6 & 6.72 \\
G1 x G7 & -5.69 & G6 x G8 & 7.85 & G8 x G7 & -2.68 \\
G1 x G8 & 3.25 & G6 x G9 & 2.74 & G8 x G9 & -7.74 \\
G1 x G9 & -1.52 & G7 x G1 & -1.56 & G9 x G1 & 3.59 \\
G3 x G6 & 5.84 & G7 x G3 & 3.45 & G9 x G3 & 1.65 \\
G3 x G7 & -0.18 & G7 x G6 & 3.24 & G9 x G6 & 4.02 \\
G3 x G8 & 9.45 & G7 x G8 & -9.31 & G9 x G7 & -11.77 \\
G3 x G9 & 2.48 & G7 x G9 & -7.58 & G9 x G8 & -2.78 \\
G6 x G1 & -5.59 & G8 x G1 & -11.19 & NK33 & 6.72 \\
G6 x G3 & -0.87 & G8 x G3 & 4.22 & & \\
\hline
\end{tabular}


Banziger, M., G.O. Edneades, D. Beck, and M. Bekon. 2000. Breeding for drought and nitrogen stress tolerance in maize. From theory to practice. D.F CIMMYT. Mexico.

Hallauer, A.R. and J.B. Miranda. 1988. Quantitative Genetics in Maize Breeding. $2^{\text {nd }}$ ed. Iowa State Univ. Press. Iowa

Micke, A. and B. Donini. 1993. Induced Mutations. In: M.D. Hayward, N.O. Bosemark and I. Romagosa (eds.). Plant Breeding: Principles and Prospects. Chapman and Hall, London. pp 52-61.

[P3TIR BATAN] Pusat Penelitian dan Pengembangan Teknologi Isotop dan Radiasi Badan Tenaga Nuklir Nasional. 2000. Present and future activities of mutation. BATAN, Jakarta.

Poehlman, J.L. 1987. Breeding Field Crops. Van Nostrand Reinhold, New York.

Rustikawati, S.H. Sutjahjo, C. Herison, dan S.I. Aisyah. 2008. Induksi mutasi melalui iradiasi sinar gamma terhadap benih untuk meningkatkan keragaman populasi dasar jagung (Zea mays L.). Akta Agrosia 11(1): 57-62
Soeranto, H. 2003. Peran iptek nuklir dalam pemuliaan tanaman untuk mendukung industri pertanian. Jakarta: Puslitbang Teknologi Isotop dan Radiasi, Badan Tenaga Nuklir Nasional (BATAN).

Taufik, M., Suprapto, dan H. Widiono. 2009. Uji daya hasil pendahuluan dan lanjutan hibrida silang ganda (double cross) berdaya hasil tinggi dan adaptif pada lahan ultisol dengan dosis pemupukan rendah tanpa pengapuran dan tanpa bahan organik. Laporan Penelitian Hibah Strategis Nasional. Lembaga Penelitian, Universitas Bengkulu.

Zaidi, P.H., P. M. Selvan , R. Sultana, A. Srivastava, A.K. Singh, G. Srinivasan, R.P. Singh, and P.P. Singh. 2007. Association between line per se and hybrid performance under excessive soil moisture stress in tropical maize (Zea mays L.). Field Crops Research 101: 117-126. 